\title{
Nutritional Status among Children Receiving Ashwagandhadi Churna with Milk in Residential Homes, Tamil Nadu, India
}

\author{
Research Article
}

\section{Sangeeta Sharma1*, Deepa Jagan², K Niraimathi ${ }^{3}$, Sridhar Sukumar ${ }^{4}$, Mohan Ramachandran 5}

\author{
1. Research Director, 2. Program Manager, 4. Trustee, 5. Founder Trustee
}

Vaishnavi Welfare \& Charitable Trust, Ramnagar, Velachery, Chennai-600042, Tamil Nadu

3. Director, Fenivi Research Solutions, Seethammal Colony, Lubdhi Colony, Alwarpet, Chennai.Tamil Nadu

\begin{abstract}
Background: Children of residential homes $(\mathrm{RH})$ have a high rate of health problems including malnutrition.Ayurveda has several drugs to alleviate malnutrition, Ashwagandhadi being one of the most commonly used drug. This study evaluated the changes in nutritional status of children in RH consuming Ashwagandhadi churna (AC) for 1-3 years. Methods: This was a retrospective descriptive record review study of children consuming AC regularly for 1-3 years of two RH of Tamilnadu during 2018-2019. The children of age 6-9 and 10-13 years received a dosage of 2 and $4 \mathrm{~g}$ of $\mathrm{AC}$ respectively in milk once a day. Socio-demographic details, anthropometric measurements and clinical details were assessed. Data at three time points with an interval of three months were extracted and analysed using Friedman's tests. Important observations and Results: Out of 289 children, 173, who had complete details of three assessments, were included for analysis. Irrespective of the years of consumption of $\mathrm{AC}$, at the first assessment, $61.6 \%$ were stunted or severely stunted; $71.2 \%$ underweight or severely underweight. Significant improvement in height-for-age and weight-for-age were observed in children consuming AC for 1 and 2 years. BMI did not show significant difference in 3 years of consumption. Males of 10 to 13 years having 1 and 2 years of consumption and females of both age groups having 2 years of consumption showed difference in BMI. Conclusion: Approximately three in ten children were malnourished in RH. Consumption of AC over a period of time improved the nutritional status of these children. Further large scale trials could prove the efficacy of AC in alleviating malnutrition.
\end{abstract}

Key Words: Karshya, Withaniasomnifera (Linn.)Dunal, malnutrition, stunting, underweight, body mass index.

\section{Introduction}

Malnutrition in children is known to pose several health issues in adult phase of life and is one of the prominent risk factors for increased health burden in developing countries (1). It is often characterized by a deficit in protein, energy or vitamins. Dietary deficits like food insecurity, lower-than-recommended breastfeeding, and poor diet can lead to insufficient protein and energy consumption, which leads to malnourishment (2). Optimal nutritional status is the state of the body with respect to each nutrient and overall body weight and condition, which is assessed using anthropometric measurements and collecting information about a client's medical history, clinical and biochemical characteristics, dietary practices, current treatment, and food security situation. It is a powerful factor in promoting health and preventing and treating

\section{* Corresponding Author:}

\section{Sangeeta Sharma}

Research Director, Vaishnavi Welfare \& Charitable

Trust, Road No.8, Plot no.402, First floor, Ramnagar,

Velachery, Chennai-600042, Tamil Nadu.

Email Id: sinoliasangeeta1981@gmail.com diseases (3). Available evidence from smaller studies for selected age groups within this cohort suggests that children ages 5-15 years suffer from high prevalence of nutritional deprivation and its consequences (4). Economic, political, and social factors like limited access to health care, poor education, unclean environment, poverty have also been associated with malnourishment (2). In addition, the available literature widely acknowledges that children and young people, who are out of home care, like those living in residential homes are a highly vulnerable group with increased physical, mental and social health needs and with limited access to resources. They are also more likely to have significant, often unrecognised and unmet health needs, increased rates of developmental difficulties and are less likely to access preventative health services.

India's performance towards the Sustainable Development Goal 2 of Zero Hunger with a distinct goal dedicated to eradicate starvation and malnutrition for the 2019 is reported as 35 (Goal 2 SDG index) and Tamil Nadu having 48 out of 100 (5). While our development agenda mirrors the requirements, national and state schemes and programmes have to be perfectly aligned to achieve the SDGs. In India, community based interventions provide support via existing primary health care centers, anganwadis and through 
government-initiated policies (6). In addition to the existing programmes such as Integrated Child Development Centre, and other government schemes, the National Nutrition Mission has been set up by the Ministry of Women and Child Development to alleviate malnutrition in children (7). Under this mission, the use of traditional plant-based foods such as Ashwagandha (Withaniasomnifera (Linn.) Dunal), Amlaki (Emblica officinalis Gaertn) and Shigru (Moringa oleifera Lam.) has been proposed by the Ministry of AYUSH to tackle malnutrition and improve the nutritional status of children (8).

Karshya, an Aptarpanjanya Vyadhi (undernutrition) mentioned in Ayurveda is comparable to malnutrition. Patients suffering from this condition subsequently suffer from Balahani (loss of immunity) and ultimately the death (9).Malnutrition results in dysfunction of Vyanvayu resulting in Agni Dushti and VataPrakopa. This leads to the malfunction of digestive, absorptive, circulatory and metabolic functions at Jatharagni and Dhatavagni level. Some of the medicines prescribed for this condition are Payasya (Ipomea digitata Linn.), Ashwagandha (Withania somnifera (Linn.) Dunal), Salparni (Desmodium gangeticum Dc), Shatavari (Asparagus racemosus Willd.), Bala (Sida cordifolia Linn.), Atibala (Abutilon indicum D.Don.) and Nagbala (Grewia hirsutaVahl.) Ashwagandha (Withania somnifera (Linn) Dunal), a root based medicine in Ayurveda, has been renowned for its anti-stress, anti-diabetic, anti-carcinogenic, neuroprotective, immunoprotective, and rejuvenating effects $(10-13,15-18)$. Ashwagandhadi is used as a dietary supplement to increase energy, prevent diseases, and to improve health, longevity, immunity and muscle mass (14). Ashwagandhadi churna has been indicated for the conditions like Pandu (anaemia), Aruci (anorexia), Ajirna (indigestion), Kshaya (weakness) and Krimi (worms). These symptoms are also seen in the children suffering from malnutrition, so this compound is widely given to children. It is reported that Ashwagandha sunnundalu (Uradladdu) supplement administered to malnourished pre-school children between 3 and 5 years of age for a 30-day period led to significant increase in height, weight and mid upperarm circumference in children (6). There are limited studies that assess the effect of Ashwangandhadhi on the nutritional status of children. Therefore, this study evaluated the changes in nutritional status of children in residential homes consuming $\mathrm{AC}$ over a period of one to three years.

\section{Materials and Methods}

\section{Study Setting}

The study was conducted at two residential homes, Residential middle school in Thirukoilur and UdavumUllangal, non-profit organization for children in crisis in Tirunelveli, Tamil Nadu. These two residential homes have children in the age range of 4 to 21 years are supported by Vaishnavi welfare and charitable trust, a non-governmental organization working towards alleviating malnutrition by using the ancient science of Ayurveda. This organization implements the 'Jeevani Milk programme', a project initiated in 2014 in which children are supplemented with AC benefitting more than 1200 school children in Tamil Nadu. The data regarding socio-demographic details, anthropometric and clinical details of children consuming AC are routinely collected.

\section{Study Design}

This was a retrospective descriptive record review study based on the data extracted from the records of two residential homes in Thirukoilur and Tirunelveli districts of Tamil Nadu during 2018-2019.

\section{Sample}

Children of the two residential schools who were continuing the consumption of $\mathrm{AC}$ for a period of one to three years were selected for the study. Children of age group 6 to 13 years of both genders were included for the study.

\section{Jeevani Milk Programme}

$\mathrm{AC}$ is given to all the children residing in the two homes, once a day either at mid morning (11.00 a.m.) or at evening (4.30 p.m.). Children of the age group less than 10 years are given a dose of $2 \mathrm{~g}$ of $\mathrm{AC}$ mixed in $150 \mathrm{~mL}$ of milk, while for children above 10 years are given $4 \mathrm{~g}$ in $200 \mathrm{~mL}$ of milk. The ingredients of AC (Sahasrayogam, Churnaprakaran) are given in Box 1. It is recommended to reduce the consumption of salt, spice and tamarind as it may have an effect on the intervention.

\section{Box 1. Ingredients in Aswagandhadhi Churna}

\begin{tabular}{l|l|l|l|l|} 
S.No & \multicolumn{2}{l}{ Name of the ingredient } & Quantity \\
\cline { 2 - 5 } & Sanskrit Name & Common Name & Botanical Name & \\
\hline 1 & Lavanga & Clove & Syzygium aromaticum & 1 part \\
\hline 2 & Nagakesara & Indian rose chest nut & Mesua ferrea & 2 parts \\
\hline 3 & Ela & Cardamom & Elettaria cardamomum & 4 parts \\
\hline 4 & Maricha & Pepper & Piper nigrum & 8 parts \\
\hline 5 & Pippali & Long pepper & Piper longum & 16 parts \\
\hline 6 & Sunthi & Dried Ginger & Zingiber officinalis & 32 parts \\
\hline 7 & Ashwagandha & Indian Ginseng & Withania somnifera & 64 parts \\
\hline 8 & Sita & Sugar & & 128 parts \\
\hline
\end{tabular}


children who are consuming $\mathrm{AC}$ for one, two and three years. Socio-demographic details, anthropometry and clinical details were extracted from the records at three time points at an interval of 3 months between assessments (June 2018, November 2018, and March 2019). The anthropometric details included height, weight and body mass index. Height-for-age, weightfor-age and BMI-for-age are recommended as feasible methods to assess the nutritional status. The collected data was entered, cleaned, coded and then analysed.

Data with missing records for outcomes were excluded for analysis. The data was segregated based on years of consumption of $\mathrm{AC}$ and subjected to descriptive analyses including frequency, percentage, median and interquartile range. Nutritional status was determined with height-for-age (severely stunted, stunted, normal, abnormal), weight-for-age (severely underweight, underweight, normal, abnormal) and Body Mass Index (BMI) (underweight, normal, overweight, obese) using the most recent nationally relevant growth references as reported by Khadilkar et al. (Appendix I) (15). Differences in the assessments were estimated using Friedman's test separately with respect to years of consumption. The significance was determined to be at 0.05 and 0.01 levels. All statistical tests were performed using SPSS 22.0 (SPSS, Chicago, IL, USA).

\section{Results}

The two RH had a total of 289 children consuming AC over a period of time in the age range of 4-21 years during 2018-2019. Out of 289 children, 116 were not included for the study, the reasons being dropped out or lost-to-follow up $(n=46)$, age below 6 or above $13(\mathrm{n}=31)$ and years of consumption of $\mathrm{AC}$ restricted to 1-3 years $(n=39)$. Thus, data of 173 children were extracted. Only records that had data of each parameter at all three assessment points were included. The final analysis included 125 children (48 missing cases) for height, 125 children (48 missing cases) for weight and 118 children (55 missing cases) for BMI. Of the 173 children, 77 consumed AC for 1 year, 75 for 2 years and 21 for three years.

\section{Socio-demographic details}

Table 1 represents the socio-demographic data of the children included for the study. Of 173 children, 144 were from the residential home at Thirukoilur and 29 from Tirunelveli, belonging to low economic status. Nearly $95 \%$ of the fathers of these children were working as coolie.

\section{Anthropometric status over three assessments}

Irrespective of the years of consumption of AC, the proportion of children under stunted and severely stunted category reduced during the third assessment. Among those children consuming AC for three years, substantial number of children moved to normal height for age (Figure 1). Similar observations were made for weight-for-age in the three groups of consumption (Figure 2).
Through the assessment points in the children consuming $\mathrm{AC}$ for one and two years, there is reduction in the number of children in the underweight category moving to the normal BMI category. In the group consuming $\mathrm{AC}$ for three years, it is found that there is an increase in the underweight category at assessment 2 and at assessment 3, the proportion of children with underweight has reduced and increased proportion in normal and overweight category was seen. It is also noted that about $15.4 \%$ of the children were found overweight in assessment 3.

\section{Table 1. Socio-demographic characteristics of children consuming Ashwagandhadi churna in two residential homes in Tamil Nadu $(n=173)$ \\ Socio-demographic characteristics \\ n (\%)}

\begin{tabular}{l|l}
$\begin{array}{l}\text { Districts } \\
\text { Tirunelveli } \\
\text { Thirukoilur }\end{array}$ & $29(16.8)$ \\
\hline $\begin{array}{l}\text { Age } \\
\text { 6-9 years }\end{array}$ & $144(83.2)$ \\
\hline $\begin{array}{l}\text { 10-13 years } \\
\text { Gender }\end{array}$ & $103(40.5)$ \\
\hline $\begin{array}{l}\text { Male } \\
\text { Female }\end{array}$ & $100(57.8)$ \\
\hline $\begin{array}{l}\text { Occupation of the father } \\
\text { Coolie }\end{array}$ & $73(42.2)$ \\
\hline Farmer & $164(94.8)$ \\
\hline Driver & $4(2.3)$ \\
\hline Business & $1(0.6)$ \\
\hline Others & $1(0.6)$ \\
\hline Missing & $1(0.6)$ \\
\hline
\end{tabular}

Annual income of the family (In Rs)

\begin{tabular}{|l|l|}
\hline Less than 10,000 & $8(4.6)$ \\
\hline $10,001-30,000$ & $19(11.0)$ \\
\hline $30,001-50,000$ & $10(5.8)$ \\
\hline $50,001-70,000$ & $54(31.2)$ \\
\hline $70,001-90,000$ & $22(12.7)$ \\
\hline Above 90,001 & $2(1.2)$ \\
\hline Missing & $58(33.5)$ \\
\hline Socio economic status & \\
\hline Very poor & $170(98.3)$ \\
\hline Poor & $2(1.2)$ \\
\hline Missing & $1(0.6)$ \\
\hline Religion & $168(97.1)$ \\
\hline Hindu & $3(1.7)$ \\
\hline Christian & $2(1.2)$ \\
\hline Missing & \\
\hline
\end{tabular}

Note. $\mathrm{n}=$ Number. $\%=$ Percentage

A substantial proportion of children in the severely stunted category moved to either to stunted or normal category. Similar trend was observed in weight and BMI (Table 2).

Table 3 depicts the changes in height-for-age, weight-for-age and BMI over three assessment points evaluated using the Friedman's test. Significant positive changes in height were observed in both gender of the age groups 6-9 and 10-13 years. For weight, significant changes were observed over three assessment points for 
children consuming $\mathrm{AC}$ for 1 and 2 years and also for males in 10-13 years age category consuming for three years. BMI did not show significant difference in 3 years of consumption. Males of 10 to 13 years having 1 and 2 years of consumption and females of both age groups having 2 years of consumption showed difference in BMI.

Figure 1. Height-for-age of children consuming Ashwagandhadi churna in two residential homes in Tamil Nadu $(\mathbf{n}=125)$

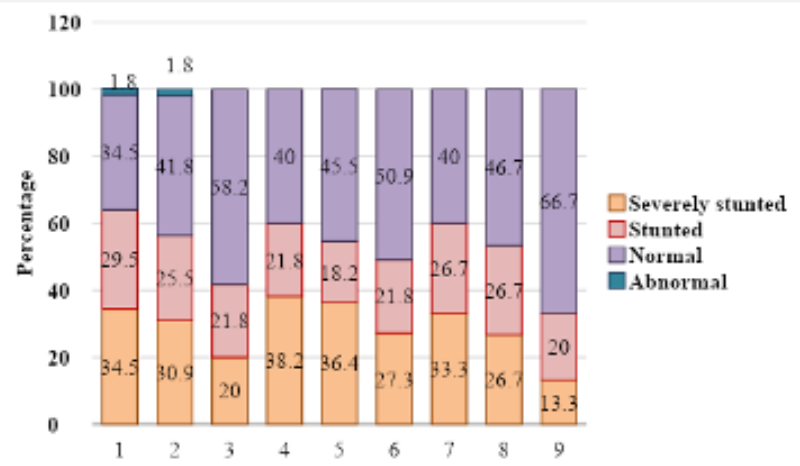

Figure 2. Weight-for-age of children consuming Ashwagandhadi churna in two residential homes in Tamil Nadu (n=125)

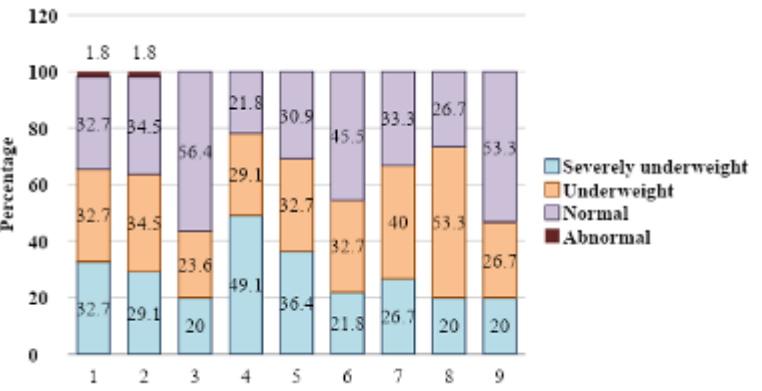

Figure 3.BMI-for-age of children consuming Ashwagandhadi churna in two residential homes in Tamil Nadu $(\mathbf{n}=118)$

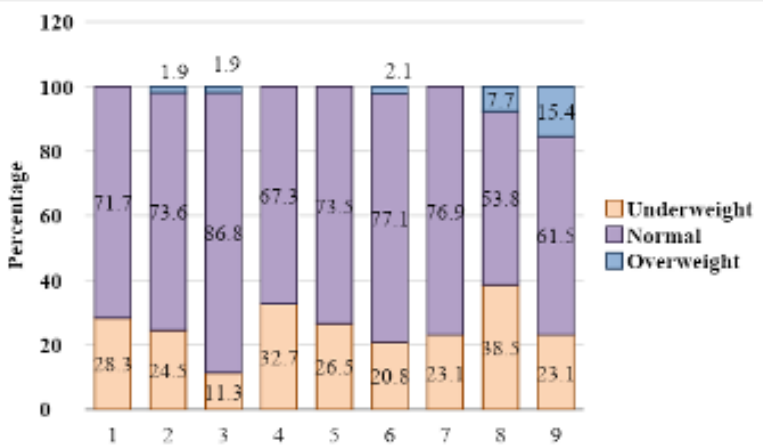

Table 2. Proportion of children at first and third assessment after consuming Ashwagandhadi churna based on height-for-age, weight-for-age and BMI-for-age in two residential homes in Tamil Nadu

\begin{tabular}{|c|c|c|c|c|c|}
\hline \multirow[t]{3}{*}{ Variable } & \multirow{3}{*}{$\begin{array}{l}\text { Years of } \\
\text { Consumption }\end{array}$} & \multirow[t]{3}{*}{ Assessment 1* } & \multicolumn{3}{|c|}{ Assessment 3} \\
\hline & & & n $(\%)$ & n $(\%)$ & n (\%) \\
\hline & & & Severely stunted & Stunted & Normal \\
\hline \multirow{11}{*}{$\begin{array}{l}\text { Height for } \\
\text { age } \\
(n=125)\end{array}$} & \multirow{4}{*}{1} & Severely stunted $(n=19)$ & $11(57.9)$ & $8(42.1)$ & - \\
\hline & & Stunted $(n=16)$ & - & $4(25.0)$ & $12(75.0)$ \\
\hline & & Normal $(n=19)$ & - & - & $19(100.0)$ \\
\hline & & Abnormal $(n=1)$ & - & - & $1(100.0)$ \\
\hline & \multirow{3}{*}{2} & Severely stunted $(n=21)$ & $13(61.9)$ & $8(38.1)$ & - \\
\hline & & Stunted $(n=12)$ & $1(8.3)$ & $2(16.7)$ & $9(75.0)$ \\
\hline & & Normal $(n=22)$ & $1(4.5)$ & $2(9.1)$ & $19(86.4)$ \\
\hline & \multirow{3}{*}{3} & Severely stunted $(\mathrm{n}=5)$ & $2(40.0)$ & $2(40.0)$ & $1(20.0)$ \\
\hline & & Stunted $(n=4)$ & - & $1(25.0)$ & $3(75.0)$ \\
\hline & & Normal $(n=6)$ & - & - & $6(100.0)$ \\
\hline & & & $\begin{array}{l}\text { Severely } \\
\text { underweight }\end{array}$ & Underweight & Normal \\
\hline \multirow{11}{*}{$\begin{array}{l}\text { Weight for } \\
\text { age } \\
(n=125)\end{array}$} & \multirow{4}{*}{1} & Severely underweight $(n=18)$ & $10(55.6)$ & $6(33.3)$ & $2(11.1)$ \\
\hline & & Underweight $(\mathrm{n}=18)$ & $1(5.6)$ & $6(33.3)$ & $11(61.1)$ \\
\hline & & Normal $(n=18)$ & - & - & $18(100.0)$ \\
\hline & & Abnormal $(n=1)$ & - & $1(100.0)$ & - \\
\hline & \multirow{3}{*}{2} & Severely underweight $(n=27)$ & $11(40.7)$ & $12(44.4)$ & $4(14.8)$ \\
\hline & & Underweight $(\mathrm{n}=16)$ & - & $6(37.5)$ & $10(62.5)$ \\
\hline & & Normal $(n=12)$ & $1(8.3)$ & - & $11(91.7)$ \\
\hline & \multirow{4}{*}{3} & Severely underweight $(n=4)$ & $2(50.0)$ & $2(50.0)$ & - \\
\hline & & Underweight $(n=6)$ & $1(16.7)$ & $2(33.3)$ & $3(50.0)$ \\
\hline & & Normal $(n=5)$ & - & - & $5(100.0)$ \\
\hline & & & Underweight & Normal & Overweight \\
\hline \multirow{6}{*}{$\begin{array}{l}\text { BMI for } \\
\text { age } \\
(n=118)\end{array}$} & \multirow{2}{*}{1} & Underweight $(\mathrm{n}=15)$ & $4(26.7)$ & $11(73.3)$ & - \\
\hline & & Normal $(n=38)$ & $2(5.3)$ & $35(92.1)$ & $1(2.6)$ \\
\hline & \multirow{2}{*}{2} & Underweight $(n=16)$ & $7(43.8)$ & $9(56.2)$ & 00.0 \\
\hline & & Normal $(n=32)$ & $3(9.4)$ & $28(87.5)$ & $1(3.1)$ \\
\hline & \multirow{2}{*}{3} & Underweight $(n=3)$ & $2(66.7)$ & $1(33.3)$ & - \\
\hline & & Normal $(n=10)$ & $1(10.0)$ & $7(70.0)$ & $2(20.0)$ \\
\hline
\end{tabular}

* Percentage represents the row percentage 
International Journal of Ayurvedic Medicine, Vol 11 (2), 205-211

Table 3. Changes in height-for age, weight-for-age and BMI over three assessments of children consuming Ashwagandhadi churna in two residential homes in Tamil Nadu

\begin{tabular}{|c|c|c|c|c|c|c|c|c|c|c|c|c|c|}
\hline \multirow{4}{*}{ Variable } & \multirow{4}{*}{ Assessment } & \multicolumn{4}{|c|}{1 year of consumption $(n=77)$} & \multicolumn{4}{|c|}{2 years of consumption $(n=75)$} & \multicolumn{4}{|c|}{3 years of consumption $(n=21)$} \\
\hline & & \multicolumn{2}{|c|}{ 6-9 years $(n=29)$} & \multicolumn{2}{|c|}{$10-13$ years $(n=48)$} & \multicolumn{2}{|c|}{ 6-9 $\operatorname{years}(n=31)$} & \multicolumn{2}{|c|}{$10-13$ years $(n=44)$} & \multicolumn{2}{|c|}{$6-9$ years $(n=10)$} & \multicolumn{2}{|c|}{$10-13$ years $(n=11)$} \\
\hline & & $\begin{array}{c}\text { Male } \\
(n=19)\end{array}$ & $\begin{array}{c}\text { Female } \\
(n=10)\end{array}$ & $\begin{array}{c}\text { Male } \\
(n=33)\end{array}$ & $\begin{array}{c}\text { Female } \\
(n=15)\end{array}$ & $\begin{array}{l}\text { Male } \\
(n=21)\end{array}$ & $\begin{array}{c}\text { Female } \\
(\mathbf{n}=10)\end{array}$ & $\begin{array}{c}\text { Male } \\
(\mathrm{n}=16)\end{array}$ & $\begin{array}{c}\text { Female } \\
(n=28)\end{array}$ & $\begin{array}{l}\text { Male } \\
(n=6)\end{array}$ & $\begin{array}{c}\text { Female } \\
(n=4)\end{array}$ & $\begin{array}{l}\text { Male } \\
(n=5)\end{array}$ & $\begin{array}{c}\text { Female } \\
(n=6)\end{array}$ \\
\hline & & M(IQ) & M(IQ) & M(IQ) & M(IQ) & M(IQ) & M(IQ) & M(IQ) & M(IQ) & M(IQ) & $\mathbf{M}(\mathbf{I Q})$ & M(IQ) & M(IQ) \\
\hline \multirow{4}{*}{ Height } & 1 & $\begin{array}{l}118.0 \\
(4.8)\end{array}$ & $\begin{array}{l}116.2 \\
(10.1)\end{array}$ & $\begin{array}{l}130.0 \\
(10.5)\end{array}$ & $\begin{array}{l}133.0 \\
(7.5)\end{array}$ & $\begin{array}{l}111.0 \\
(7.0)\end{array}$ & $\begin{array}{l}111.5 \\
(3.3)\end{array}$ & $\begin{array}{l}128.0 \\
(11.0)\end{array}$ & $\begin{array}{l}130.0 \\
(7.5)\end{array}$ & $\begin{array}{l}116.0 \\
(17.0)\end{array}$ & $\begin{array}{l}118.1 \\
(10.5)\end{array}$ & $\begin{array}{l}131.5 \\
(9.8)\end{array}$ & $\begin{array}{c}120.0 \\
(0)\end{array}$ \\
\hline & 2 & $\begin{array}{l}118.5 \\
(7.8)\end{array}$ & $\begin{array}{l}116.7 \\
(10.3)\end{array}$ & $\begin{array}{l}131.5 \\
(10.5)\end{array}$ & $\begin{array}{l}135.0 \\
(8.0)\end{array}$ & $\begin{array}{l}115.0 \\
(6.0)\end{array}$ & $\begin{array}{l}113.2 \\
(3.1)\end{array}$ & $\begin{array}{l}129.0 \\
(9.0)\end{array}$ & $\begin{array}{l}132.0 \\
(8.5)\end{array}$ & $\begin{array}{l}116.0 \\
(17.0)\end{array}$ & $\begin{array}{l}116.0 \\
(11.3)\end{array}$ & $\begin{array}{l}134.0 \\
(11.8)\end{array}$ & $\begin{array}{c}120.0 \\
(0)\end{array}$ \\
\hline & 3 & $\begin{array}{l}120.0 \\
(7.5)\end{array}$ & $\begin{array}{c}119.0 \\
(16.3)\end{array}$ & $\begin{array}{l}133.5 \\
(12.5)\end{array}$ & $\begin{array}{l}137.0 \\
(9.0)\end{array}$ & $\begin{array}{l}116.0 \\
(7.0)\end{array}$ & $\begin{array}{l}115.2 \\
(2.3)\end{array}$ & $\begin{array}{l}132.0 \\
(10.5)\end{array}$ & $\begin{array}{l}136.0 \\
(6.8)\end{array}$ & $\begin{array}{l}120.0 \\
(17.5)\end{array}$ & $\begin{array}{l}119.5 \\
(12.8)\end{array}$ & $\begin{array}{l}137.0 \\
(12.8)\end{array}$ & $\begin{array}{l}123.0 \\
(0)\end{array}$ \\
\hline & $\mathrm{p}$ value $\$$ & $0.000^{* *}$ & $0.022 *$ & $0.000 * *$ & $0.000^{* *}$ & $0.000 * *$ & $0.000^{* *}$ & $0.000 * *$ & $0.000^{* *}$ & $0.011^{*}$ & $0.018^{*}$ & $0.030^{*}$ & - \\
\hline \multirow{4}{*}{ Weight } & 1 & $\begin{array}{l}18.0 \\
(3.8)\end{array}$ & $\begin{array}{l}17.5 \\
(7.3)\end{array}$ & $\begin{array}{l}25.0 \\
(6.3)\end{array}$ & $\begin{array}{l}26.0 \\
(5.5)\end{array}$ & $\begin{array}{l}17.0 \\
(4.0)\end{array}$ & $\begin{array}{l}15.5 \\
(3.5)\end{array}$ & $\begin{array}{l}21.0 \\
(4.0)\end{array}$ & $\begin{array}{l}25.0 \\
(5.5)\end{array}$ & $\begin{array}{l}18.0 \\
(6.5)\end{array}$ & $\begin{array}{l}18.0 \\
(8.8)\end{array}$ & $\begin{array}{l}25.0 \\
(8.3)\end{array}$ & $\begin{array}{l}20.5 \\
(0)\end{array}$ \\
\hline & 2 & $\begin{array}{l}18.5 \\
(3.3)\end{array}$ & $\begin{array}{l}19.0 \\
(6.5)\end{array}$ & $\begin{array}{l}24.0 \\
(7.3)\end{array}$ & $\begin{array}{l}27.0 \\
(6.5)\end{array}$ & $\begin{array}{l}18.0 \\
(3.0)\end{array}$ & $\begin{array}{l}17.0 \\
(3.5)\end{array}$ & $\begin{array}{l}22.0 \\
(4.5)\end{array}$ & $\begin{array}{l}26.0 \\
(6.0)\end{array}$ & $\begin{array}{l}18.0 \\
(7.5)\end{array}$ & $\begin{array}{c}19.0 \\
(11.8)\end{array}$ & $\begin{array}{l}25.0 \\
(9.0)\end{array}$ & $\begin{array}{l}20.5 \\
(0)\end{array}$ \\
\hline & 3 & $\begin{array}{l}20.0 \\
(3.0)\end{array}$ & $\begin{array}{l}21.2 \\
(9.5)\end{array}$ & $\begin{array}{l}26.5 \\
(8.0)\end{array}$ & $\begin{array}{l}28.0 \\
(9.5)\end{array}$ & $\begin{array}{l}18.0 \\
(4.0)\end{array}$ & $\begin{array}{l}18.0 \\
(4.4)\end{array}$ & $\begin{array}{l}24.0 \\
(4.5)\end{array}$ & $\begin{array}{l}29.0 \\
(7.3)\end{array}$ & $\begin{array}{c}18.0 \\
(16.5)\end{array}$ & $20.5(12.3)$ & $\begin{array}{c}25.0 \\
(13.0)\end{array}$ & $21.0(0)$ \\
\hline & $\mathrm{p}$ value $\$$ & $0.001 * *$ & $0.039^{*}$ & $0.000^{* *}$ & $0.027^{*}$ & $0.020^{*}$ & $0.000^{* *}$ & $0.000^{* *}$ & $0.000^{* *}$ & $0.291 \mathrm{NS}$ & $0.057 \mathrm{NS}$ & $0.020 *$ & - \\
\hline \multirow{4}{*}{ BMI } & 1 & $\begin{array}{l}12.8 \\
(1.3)\end{array}$ & $\begin{array}{l}13.5 \\
(3.8)\end{array}$ & $\begin{array}{l}14.2 \\
(1.3)\end{array}$ & $\begin{array}{l}14.7 \\
(2.7)\end{array}$ & $\begin{array}{l}13.0 \\
(1.4)\end{array}$ & $\begin{array}{l}13.1 \\
(2.1)\end{array}$ & $\begin{array}{l}13.1 \\
(1.2)\end{array}$ & $\begin{array}{l}14.4 \\
(2.1)\end{array}$ & $12.6(2.1)$ & $\begin{array}{l}13.6 \\
(3.4)\end{array}$ & $\begin{array}{l}13.7 \\
(3.6)\end{array}$ & $\begin{array}{l}14.2 \\
(0)\end{array}$ \\
\hline & 2 & $\begin{array}{l}13.1 \\
(1.9)\end{array}$ & $\begin{array}{l}13.5 \\
(2.8)\end{array}$ & $\begin{array}{l}13.6 \\
(1.5)\end{array}$ & $\begin{array}{l}15.2 \\
(2.9)\end{array}$ & $\begin{array}{l}13.4 \\
(1.3)\end{array}$ & $\begin{array}{l}13.2 \\
(2.4)\end{array}$ & $\begin{array}{l}13.3 \\
(2.0)\end{array}$ & $\begin{array}{l}14.7 \\
(2.2)\end{array}$ & $12.6(2.1)$ & $\begin{array}{l}14.1 \\
(5.0)\end{array}$ & $\begin{array}{l}13.7 \\
(3.9)\end{array}$ & $\begin{array}{c}14.0 \\
(0)\end{array}$ \\
\hline & 3 & $\begin{array}{l}13.7 \\
(2.0)\end{array}$ & $\begin{array}{l}14.0 \\
(3.3)\end{array}$ & $\begin{array}{l}14.7 \\
(1.4)\end{array}$ & $\begin{array}{l}15.0 \\
(2.8)\end{array}$ & $\begin{array}{l}13.6 \\
(1.9)\end{array}$ & $\begin{array}{l}14.0 \\
(2.6)\end{array}$ & $\begin{array}{l}14.7 \\
(1.8)\end{array}$ & $\begin{array}{l}14.8 \\
(2.9)\end{array}$ & $12.5(1.0)$ & $\begin{array}{l}14.3 \\
(4.4)\end{array}$ & $\begin{array}{l}13.5 \\
(7.3)\end{array}$ & $\begin{array}{l}14.1 \\
(0)\end{array}$ \\
\hline & p values & $0.083 \mathrm{NS}$ & $0.174 \mathrm{NS}$ & $0.011^{*}$ & $0.867 \mathrm{NS}$ & 0.307 NS & $0.000 * *$ & $0.001 * *$ & $0.006^{* *}$ & $0.819 \mathrm{NS}$ & $0.368 \mathrm{NS}$ & $0.819^{\mathrm{NS}}$ & - \\
\hline
\end{tabular}

Note. $\mathrm{BMI}=$ Body Mass Index. $\mathrm{M}=$ Median. IQ=Interquartile range. $\$=$ Friedman's test. $* *=$ Significant at 0.01 Level.

$*=$ Significant at 0.05 Level. NS=Not significant

\section{Clinical signs and symptoms over three assessments}

The clinical signs and symptoms reported among the children at the first assessment were weakness $(n=24)$, fatigue $(n=16)$, palpitation $(n=25)$, effort tolerance $(n=22)$, breathlessness $(n=32)$, ringing of ears $(n=15)$, loss of appetite $(n=17)$, giddiness $(n=17)$, sleepiness $(n=16)$, cramps in calf muscles $(n=15)$, headache $(n=24)$ and pain in legs $(n=25)$. At the third assessment, no children had palpitation, giddiness and cramps in muscle. There was a reduction in weakness $(n=4)$, fatigue $(n=5)$, effort tolerance $(n=1)$, breathlessness $(n=1)$, ringing of ears $(n=2)$, loss of appetite $(\mathrm{n}=1)$, sleepiness $(\mathrm{n}=1)$, headache $(\mathrm{n}=1)$ and pain in leg $(n=1)$.

\section{Discussion}

Our study observed the children in RH for nine months revealing significant improvements in the nutritional status in terms of height-for-age, weight-forage and BMI from the first to third assessment, however variations were observed in gender and age.

The study has few limitations as it was a record review study. The nutritional status of the children at $\mathrm{RH}$ before consuming $\mathrm{AC}$ was not available. Children in RH go to their homes during the holidays, during which they did not consume AC for few weeks. But in the present study, the assessment period was during academic period so there was no break in the AC consumption. As the measurements were not recorded at all assessments points for many children, they had to be excluded from analysis. Therefore, subgroup analysis could be conducted. The study sample was homogeneous in the dietary pattern as they stay in the $\mathrm{RH}$, which is the strength of the study.

Our study witnessed significant improvement in height-for-age and weight-for-age in those consuming $\mathrm{AC}$ for one and two years. A recent study conducted in malnourished preschool children comparing Ayurvedic Ghrita and ICDS nutrition mix showed that the former showed improved appearance, appetite, sleep, bowel habit, general weakness and interest in activities (16). Another study conducted in ICDS children showed a trend of improvement which was observable and measurable despite the supplementation period being short for 30 days (17). This reveals the importance of provision of ayurvedic drugs in addition to adequate nutrition to improve the overall health status of children. Female children falling under 10-13 years age category who consumed the AC for three years reported changes, however the difference was not statistically significant. This was probably due to their low representation in the particular group which was inadequate to show statistical significance. It is assumed that consumption of $\mathrm{AC}$ over a period of time improves the nutritional status. However in the present study, children consuming AC for 3 years, 33\% severely stunted and $23 \%$ were underweight. The first assessment was taken as soon after the school vacation. Among three years group, the proportion of underweight children increased during $2^{\text {nd }}$ assessment. The reasons for this sudden reduction in the weight require further exploration.

In this study, all the children were given AC with milk. Milk is an economically viable vehicle which has a high nutrient-energy ratio. However, it is recommended that ghee and honey can also be used as a vehicle to deliver AC based on the body condition. A trial comparing Ashwagandha Ghrita (drug mixed with ghee) and granules showed that the former showed $34.97 \%$ improvement in symptoms while the latter showed $23.72 \%$ improvement, establishing the importance of Anupana (18). Ashwagandha Ghrita Matrabasti reinstates the altered Kapha and Pitta to its normal state which also brings the equilibrium in Agni. Thus it is known to improve the growth of the malnourished child by improving the Vata, Snigdha guna and the Dhatwagni of Rasa, Mamsa and Medas of the malnourished child (19).Therefore, future studies 
need to consider the appropriate vehicle for AC delivery based on the body condition.

Malnourished children have weak immunity and are prone to several infectious diseases (1). Ashwagandha has been found to exhibit antimicrobial and antifungal properties with inhibitory action towards several bacillus and Candida species such as $B$. anthracis, S. typhi, C. pneumonia, C. albicans, E. coli, $B$. thruengenesis and $P$. aeruiginosa. Ashwagandha is rich in natural alkaloids and steroids that stimulates synthesis of protein, increase lipophilic activity in the cells, increase vitality and promote the growth and development of children (20-22). In the present study, it was observed that a good proportion of children exhibiting clinical signs and symptoms showed reduction in $4^{\text {th }}$ and $9^{\text {th }}$ month assessment.

Along with Ashwagandha, the other ingredients in the formulation used in the present study help to increase the Agni (digestive fire). In malnourished children, loss of appetite and poor absorption are some of the important concerns. Poor digestion and absorption are unhelpful in this condition as growth is hindered despite being provided with nutritious meals. Hence, it is critical to address the problem in metabolism of nutrients, which is taken care of by Ashwagandhadi churna. Ashwagandha's Rasa (taste) is a combination of Madhura (sweet), Kashaya (astringent) and Tikta (bitter), stimulating Vipaka (sweet post digestive effect) and has Virya (hot potency) (23). Ingredients such as black pepper, long pepper and dried ginger are excellent carminative agents which help in increasing the digestive fire, thus helping in improving the Agni of the children. Thus AC can act as an effective drug to alleviate malnourishment in children and improve their nutritional status over regular consumption.

The learning from the study resulted in streamlining the data documentation process of Jeevani Milk Programme in all the homes.

\section{Conclusion}

Approximately three in ten children were malnourished in residential homes. Consumption of Ashwagandhadi over a period of time improved the nutritional status of these children. Further large scale studies can be conducted to evaluate the efficacy of Ashwagandhadi churna in detail thus enabling to benefit a large proportion of malnourished children in India.

\section{Acknowledgments}

We acknowledge Dr PLT Girija for inspiring us in initiating the Jeevani Milk Programme. We thank Dr Tamilarasi, Dr Vasudharini, Dr Kanakadhara, Dr Ashok, DrLoha Devi for assisting in acquisition of data. We thank Mr. Lakshmi Narasimhan for his assistance in analysing the data. We thank for their assistance in drafting and editing the manuscript and data analysis. We thank the residential homes to permit to conduct this programme.

\section{References}

1. Müller O, Krawinkel M. Malnutrition and health in developing countries. Vol. 173, CMAJ. 2005. p. 279-86.

2. Bhutta ZA, Berkley JA, Bandsma RHJ, Kerac M, Trehan I, Briend A. Severe childhood malnutrition.
Vol. 3, Nature reviews. Disease primers. 2017. p. 17067.

3. Food and Nutrition Technical Assistance III Project, (FANTA). Nutrition Assessment, Counseling, and Support (NACS): A User's Guide-Module 2: Nutrition Assessment and Classification, Version 2. DC, Washington: FHI 360/FANTA.; 2016.

4. Galloway R. Disease Control Priorities, Third Edition (Volume 8): Child and Adolescent Health and Development. Disease Control Priorities, Third Edition (Volume 8): Child and Adolescent Health and Development. The World Bank; 2017.

5. SDG India - Index \& Dashboard 2019-20 | NITI Aayog [Internet]. [cited 2020 Feb 27]. Available from: https://niti.gov.in/sdg-india-indexdashboard-2019-20

6. Sarada D, Punitha A. Efficacy of Ashwagandha Sunnundalu as a Nutritional Supplement for Anganwadi (ICDS) Children. 2016;2(5):660-5.

7. Ministry of Women and Child Development. National Nutrition Mission to improve the nutritional indicators of women and children [Internet]. Press Information Bureau India. [cited 2020 Jan 21]. Available from: https://pib.gov.in/ newsite/PrintRelease.aspx?relid $=176441$

8. Kaul R. To curb malnutrition, Centre banks on desi 'superfoods' - india news. Hindustan Times [Internet]. [cited 2020 Jan 21]; Available from: https://www.hindustantimes.com/india-news/tocurb-malnutrition-centre-banks-on-desi-superfoods/ story-bTQliun5ViSgyHlyUJ26gN.html

9. Majumder M. Review OfKarshya W.S.R. To Undernutrition. Int Ay urvedic Med J. 2017;5(4):2320-5091.

10. Braun L, Cohen M. Herbs and natural supplements. Volume 1: an evidence-based guide. 237 p.

11. Singh G, Sharma PK, Dudhe R, Singh S. Biological Activities of WithaniaSomnifera. 2010;56-63.

12. Vyas VK, Pratik B, Radheshyam P. A Comprehensive Revi ew o n WithaniaSomniferaDunal. cabdirect.org. 2011;1-13.

13. Upton R, Graff A, Evans F. Ashwagandha Root: WithaniaSomnifera: Analytical, Quality Control, and Therapeutic Monograph. 2000;1-25.

14. Wankhede S, Langade D, Joshi K, Sinha SR, Bhattacharyya S. Examining the effect of Withaniasomnifera supplementation on muscle strength and recovery: A randomized controlled trial. J IntSoc Sports Nutr. 2015 Nov;12(1).

15. Khadilkar V, Yadav S, Agrawal KK, Tamboli S, Banerjee M, Cherian A, et al. Revised IAP Growth Charts for Height, Weight and Body Mass Index for 5-to 18-year-old Indian Children. Vol. 47, Indian Paediatrics. 2015.

16. Mallannavar V, Raj AG, Viswaroopan D, Kumar Bharati A, Professor A. EFFECT OF K A R S Y A H A A Y O G IN THE MANAGEMENT OF MALNUTRITION IN PRESCHOOL CHILDREN. Int J Res Ayurveda Pharm [Internet]. 2017 [cited 2020 Jan 17];8(2):40. Available from: www.ijrap.net

17. Sarada D, Punitha A. Efficacy of AshwagandhaSunnundalu as a Nutritional Supplement for Anganwadi (ICDS) Children. 2016 [cited 2019 Dec 9];2(5):660-5. Available from: www.allresearchjournal.com

18. Mishra R, Trivedi R, Pandya M. A clinical study of Ashwagandhaghrita and Ashwagandha granules for 
its Brumhana and Balya effect.AYU (An Int Q J Res Ayurveda). 2010;31(3):355.

19. Viswaroopan D, Uppinakudru S, Raj A, Raj J, Patil S. Ayurvedic management of underweight in children at a tertiary care teaching hospital of Southern India: A pilot clinical study. Int J Res Ayurveda Pharm. 2016 Jul 15;7(4):46-9.

20. Upadhyay PS, Singh K. AshwagandhaGhrita in BalKarshya (Childhood Undernutrition). Int J Heal Sci Res [Internet]. 2019 [cited 2020 Jan 17];9(7):271. Available from: www.ijhsr.org

21. Viswaroopan D, Raj AGR, Uppinakudru S. Standardization of AshwagandhaGhrita : A Herbal
Ghee Based Ayurvedic Medicinal Preparation. Int J Pharm Sci Res. 2016;7(2):819-23.

22. Viswaroopan D, Maurya D, Gawade S, Raj JK, Raj AG. The Pharma Innovation Journal 2015; 4(4): 85-89 Preparation of A shwagandha (WithaniaSomnifera (L.) Dunal) ghee-A practical approach inspired by traditional knowledge. TPI [Internet]. 2015 [cited 2020 Jan 10];4(4):85-9. Available from: www.thepharmajournal.com

23. Pilmeijer A. Cancer \& Ayurveda as a Complementary Treatment.Int J Complement Altern Med [Internet]. 2017 [cited 2020 Feb 5];6(5):00202. Available from: http://medcraveonline.com

Appendix I Standard table used for referencing nutritional status of the children

\begin{tabular}{|c|c|c|c|c|c|c|c|c|c|c|c|c|c|}
\hline \multirow[b]{2}{*}{ Age } & \multirow[b]{2}{*}{ Sex } & \multicolumn{4}{|c|}{ Height } & \multicolumn{4}{|c|}{ Weight } & \multicolumn{4}{|c|}{ BMI } \\
\hline & & $\begin{array}{c}\text { Abnormal } \\
\left(97^{\text {th }}\right)\end{array}$ & $\begin{array}{c}\text { Normal } \\
\left(1^{\text {th_-90 }}{ }^{\text {th }}\right)\end{array}$ & $\begin{array}{c}\text { Stunted } \\
\left(3^{\text {rd }}\right)\end{array}$ & $\begin{array}{c}\text { Severely } \\
\text { stunted } \\
\left(<3^{\text {rd }}\right)\end{array}$ & $\begin{array}{c}\text { Abnormal } \\
\left(97^{\text {th }}\right)\end{array}$ & $\begin{array}{c}\text { Normal } \\
\left(10^{\text {th }}-90^{\text {th }}\right)\end{array}$ & $\begin{array}{c}\text { Under- } \\
\text { weight } \\
\left(3^{\text {rd }}\right)\end{array}$ & $\begin{array}{c}\text { Severely } \\
\text { under- } \\
\text { weight }\end{array}$ & $\begin{array}{c}\text { Under- } \\
\text { weight } \\
\text { (3rdper) }\end{array}$ & $\begin{array}{l}\text { Normal } \\
\text { (5-50th) }\end{array}$ & $\begin{array}{c}\text { Over- } \\
\text { weight } \\
\text { (71th) }\end{array}$ & $\begin{array}{c}\text { Obese } \\
\left(90^{\text {th }}\right)\end{array}$ \\
\hline \multirow[t]{2}{*}{6} & Boy & 126.0 & $107.7-122.2$ & 104.2 & $<104.2$ & 28.3 & $15.8-24.6$ & 14.5 & $<14.5$ & 12.2 & $12.5-14.9$ & 16.0 & 17.8 \\
\hline & Girl & 125.6 & $106.0-121.5$ & 102.3 & $<102.3$ & 29.1 & $15.1-29.1$ & 13.7 & $<13.7$ & 12.0 & $12.2-14.5$ & 15.9 & 18.6 \\
\hline \multirow[t]{2}{*}{7} & Boy & 132.6 & $113.0-128.6$ & 109.3 & $<109.3$ & 33.4 & $17.6-28.6$ & 16.0 & $<16.0$ & 12.3 & $12.6-15.1$ & 16.3 & 18.2 \\
\hline & Girl & 131.9 & $111.4-127.7$ & 107.4 & $<107.4$ & 33.4 & $16.8-28.2$ & 15.1 & $<15.1$ & 12.1 & $12.4-14.9$ & 16.4 & 19.3 \\
\hline \multirow[t]{2}{*}{8} & Boy & 139.1 & $118.2-134.8$ & 114.3 & $<114.3$ & 39.4 & $19.5-33.2$ & 17.5 & $<17.5$ & 12.5 & $12.8-15.5$ & 16.7 & 18.8 \\
\hline & Girl & 138.1 & $116.8-133.9$ & 112.6 & $<112.6$ & 38.1 & $18.7-32.2$ & 16.7 & $<16.7$ & 12.3 & $12.6-15.3$ & 16.9 & 20.1 \\
\hline \multirow[t]{2}{*}{9} & Boy & 145.3 & $123.2-140.7$ & 119.0 & $<119.0$ & 45.5 & $21.5-38.0$ & 19.1 & $<19.1$ & 12.7 & $13.0-15.9$ & 17.3 & 19.6 \\
\hline & Girl & 144.5 & $122.4-140.2$ & 117.8 & $<117.8$ & 43.4 & $20.9-36.7$ & 18.5 & $<18.5$ & 12.4 & $12.8-15.8$ & 17.6 & 21.0 \\
\hline \multirow[t]{2}{*}{10} & Boy & 151.4 & $128.1-146.6$ & 123.6 & $<123.6$ & 51.8 & $23.5-43.0$ & 20.7 & $<20.7$ & 12.9 & $13.2-16.4$ & 18.0 & 20.5 \\
\hline & Girl & 150.8 & $128.1-146.4$ & 123.3 & $<123.3$ & 49.4 & $23.5-42.0$ & 20.7 & $<20.7$ & 12.7 & $13.1-16.5$ & 18.4 & 21.9 \\
\hline \multirow[t]{2}{*}{11} & Boy & 157.5 & $133.0-152.5$ & 128.2 & $<128.2$ & 58.7 & $25.9-48.7$ & 22.6 & $<22.6$ & 13.1 & $13.5-17.0$ & 18.7 & 21.5 \\
\hline & Girl & 156.8 & $133.7-152.4$ & 128.8 & $<128.8$ & 55.9 & $26.7-47.7$ & 23.3 & $<23.3$ & 13.0 & $13.4-17.2$ & 19.3 & 23.0 \\
\hline \multirow[t]{2}{*}{12} & Boy & 163.7 & $138.3-158.6$ & 133.2 & $<133.2$ & 66.1 & $28.7-54.8$ & 24.9 & $<24.9$ & 13.3 & $13.8-17.7$ & 19.5 & 22.6 \\
\hline & Girl & 162.0 & $138.9-157.5$ & 134.0 & $<134.0$ & 62.1 & $30 .-53.4$ & 26.2 & $<26.2$ & 13.4 & $13.9-18.0$ & 20.2 & 24.1 \\
\hline \multirow[t]{2}{*}{13} & Boy & 169.9 & $143.7-164.7$ & 138.3 & $<138.3$ & 72.6 & $31.8-60.7$ & 27.5 & $<27.5$ & 13.6 & $14.0-18.2$ & 20.2 & 23.4 \\
\hline & Girl & 165.9 & $142.9-161.3$ & 138.2 & $<138.2$ & 67.1 & $33.1-67.1$ & 28.9 & $<28.9$ & 13.9 & $14.4-18.8$ & 21.1 & 25.2 \\
\hline
\end{tabular}

Source: Khadilkar et al. (2011) 